\title{
OBITUARY
}

\section{Prof. J. K. Robertson}

John Kellock RoBertson, professor emeritus of physies in Queen's University, Kingston, Ontario, died suddenly in London on June 24.

Robertson came to Queen's as a lecturer in physics in 1909. He had entered the University of Toronto on a classics scholarship, but took his degree in mathematics and physies and spent two graduate years as demonstrator in physics. Except for two interludes of a year each, he remained at Queen's until his retirement from his posts as professor of physics and head of the Department in 1951. The session of 1912-13 he spent at the Cavendish Laboratory, Cambridge, and as a member of Emmanuel College. During 1933-34, he was a visiting professor at the Imperial College of Science and Technology, London.

As a physicist, Robertson's major interests were in the fields of optics and of $\mathrm{X}$-rays and radiology. His text-book, "Introduction to Physical Optics" (1929), has run through successive editions, as did his "X-Rays and X-Ray Apparatus" (1924) and his "Radiology Physies" (1941).

$\mathrm{He}$ was an enthusiastic, patient and lucid teacher. His most distinctive courses of lectures were those which he gave to medical students. He was able to persuade his medical colleagues that the study of physics should be continued through two years, allowing more extensive work than was usual in North American medical schools. $\mathrm{He}$ was greatly pleased when the members of the last medical class which he taught made him an honorary life member of the class. His interest in medical physics continued after he gave up teaching, and he was an honorary member of the British Institute of Radiology and of the Association of Hospital Physicists.

He was elected Fellow of the Royal Society of Canada in 1926, was president of Section III in I94243 and president of the Society in 1944-45. After his retirement, when he spent at least part of each year in London, he represented the Royal Society of Canada and the National Research Council at a number of international gatherings.

Robertson was a literate physicist with a wide range of interests and friends. He had a talent for explaining physics to the layman ("Atomic Artillery and the Atom Bomb", 1945) and an active interest in literature.

He was a fourth-generation Canadian, born in 1885 , in Perth, Ontario, which had begun as a Scots settlement some sixty years earlier. In 1932 he published a charming little book, "Sketches of" Tayville", which had appeared earlier in the Queen's Quarterly, and which recalled his boyhood in a Scottish-Canadian town.

'J.K.' was a man of warm friendships and strong loyalties. He had a contagious enthusiasm for learning and scholarship. His gallantry turned what might have been a lonely retirement into a lively enjoyment of friendships and intellectual interests. $\mathrm{He}$ is gratefully remembered by former students and colleagues, by his brothers in the craft and by many friends on both sides of the Atlantic.

W. A. Mackintosh

\section{NEWS and VIEWS}

\section{National Standards Laboratory, Sydney :} Mr. N. A. Esserman

Mr. N. A. Esserman, chief of the Division of Metrology, has been appointed as the first director of the Commonwealth Scientific and Industrial Research Organization, National Standards Laboratory, Sydney. This appointment is one of the first consequences of the recommendations of a committee of the Advisory Council which reported last year on the future development of the National Standards Laboratory. Mr. Esserman was born and educated in Sydney, graduating in science with honours at the University of Sydney in 1916. Following a period during and after the First World War at the Arsenal Branch, London, he returned to Australia to join the Commonwealth Department of Defence, later becoming senior physicist, Munitions Supply Laboratories, at Maribyrnong in 1929, and assistant superintendent of laboratories in 1938. During this time, Mr. Esserman had accumulated a wide experience of metrology and general physical instrumentation and their application in the engineering industries. He was therefore well situated to assume the task of developing the newly created National Standards Laboratory when he was appointed senior officer-incharge of the Metrology Section in 1939. Mr. Esserman took a major share in piloting this young establishment through the turbulent years of the Second World War. The virile engineering industries which have grown to maturity in Australia in the post-war years owe a great deal to the knowledge and experience which $\mathrm{Mr}$. Esserman brought to his labours at the National Standards Laboratory. He also undertook, during the War, a number of other tasks associated with the general effort of munitions production in Australia. He was a member of the Optical Munitions Panel, the Australian Council for Aeronautics, and the Optical Advisory Panel of the Department of Post-War Reconstruction. Mr. Esserman is an active member of many scientific institutions in Australia, having held office as president of the Royal Society of Victoria, Fellow of the Australian National Research Council, chairman of the New South Wales Division of the Australian Branch of the Institute of Physics, trustee of the Sydney Museum of Applied Arts and Sciences, and member of the Technical Education Advisory Council and the International Committee of Weights and Measures. Mr. Esserman will retain his responsibilities as chief of the Division of Metrology.

\section{Dr. G. H. Briggs}

Dr. G. H. BrIGGS, who is retiring as chief of the Division of Physics of the National Standards Laboratory, graduated in 1916 at the University of Sydney and was appointed lecturer and later assistant professor of physics at that University. His Ph.D. degree was gained in research in association with 